\title{
Organic Dairy Cattle Breeding in Turkey: A Review
}

\author{
Sibel Alapala Demirhan \\ Department of Animal Sciences, Faculty of Agriculture and Natural Science, Usak University, Usak 64300, Turkey
}

\begin{abstract}
Organic animal breeding means the production of certified animal products by considering the well-being of animals without damaging the environment and without using any pesticide in a controlled manner. All aquaculture activities other than organic farming can be defined as conventional farming. Organic animal production has increased significantly annually over the past decade in the world. Dairy cattle production is examined with particular focus on the possibilities of improving the sustainability of ruminant systems and on the possible role of organic production to meet the demand of sustainability. Organic dairy cattle production can improve animal welfare, protect the environment and sustain rewarding rural life styles. Future of organic dairy cattle production will have to rely on continuous search for alternatives in nutrition, disease prevention and control that are environmentally friendly. Understanding organic dairy cattle farming from economic, ecological and animal welfare perspectives will increase the likelihood of success. In the current study, besides the basic principles of organic dairy cattle breeding that is a quite popular branch of business in recent years, the current state, weaknesses and strengths of organic dairy cattle breeding both in Turkey and the world and how organic dairy cattle breeding can be developed are discussed.
\end{abstract}

Key words: Organic animal raising, organic milk, animal health and well-being, sustainability.

\section{Introduction}

Rapid increase in the world population and increasing demand for animal products result in intensified efforts for animal husbandry. As the priority in the sector of animal husbandry is to attain high efficiency for each animal and cost-efficiency, its effects on ecological balance can be easily overlooked [1].

Use of chemicals, such as hormones and antibiotics, in feeding of animals results in traces left in animal products that pose threat to human health [2]. Organic animal breeding has come to the fore as a new alternative to prevent some problems experienced in conventional animal breeding, to enhance the welfare of animals and to yield products more beneficial for human health [3]. Organic animal breeding can be defined as a certified and controlled method of production, aiming to reestablish the natural balance destroyed as a result of erroneous applications in the ecological system, to keep synthetic-chemical substances away from the environment of production,

Corresponding author: Sibel Alapala Demirhan, assistant professor, research field: comparing organic and conventional dairy cattle breeding. to include alternative methods in fight against diseases and pesticides and to enhance not only the quantity but also the quality of products quite sensitive to the health of humans and environment [4].

In organic animal farming, farm animals are allowed to behave as they do in their natural environment; are fed with ecological animal feeds; hormone and antibiotics, etc., are not used to increase the production; healthier foods are produced for consumers; thus, it can be defined as an environmentally friendly way of production [5]. Within this production method, caring, feeding, sheltering, animal feed handling, prevention of diseases and veterinary interventions are conducted according to organic animal farming regulations, and the suitability of all the operations are controlled by an independent auditing organization.

Turkey holds an important potential for organic agriculture and animal farming with its geographical conditions, unpolluted environment, variety of vegetative and animal products, local cattle and sheep population well adapted to regional conditions, natural meadows and ranges, increasing areas for animal feed 
production and sufficient labor force [6]. The potential particularly existing for dairy cattle production should be utilized.

Organic dairy cattle breeding method, such as taking care of animals, accommodation of animals, fertilizer management, preventing illnesses and veterinary practices, are all carried out according to organic agriculture directives and are all proctored by an independent control authority. It is very important that the cows to be selected as the brood stock for milk and meat production should be resistant against different climates and illnesses.

\section{The Basic Principles of Organic Dairy Cattle Breeding}

According to the bylaw "principles of organic agriculture and its applications" issued by the Ministry of Food, Agriculture and Livestock [7], all the agricultural activities other than organic agricultural activities are defined as conventional agriculture. On the basis of this definition, all the animal raising activities, except for organic animal raising, can be defined as conventional animal raising.

In Turkey, "organic agriculture law" was put into effect to produce organic products and inputs, so that consumers can be provided with safe and quality products [4].

With the issuing of the bylaw "principles of organic agriculture and its applications" on August 18, 2010 with the number of 27,676 in the official gazette in Turkey, the rules to be followed in the production of organic products from livestock raising are summarized as follows [7]:

(1) For the production of organic animal products, breeds which have strong capacity of adaptation to environmental conditions and are disease resistant should be selected, and in this line, local breeds and/or hybrid breeds that have already adapted to the region should be given priority;

(2) Organizations raising organic animals and producing organic animal products must keep regular records related to arrival and leaving of animals and treatment interventions to these animals;

(3) There are some rules related to supply of animal feed and feeding of animals in organic animal breeding. Animals must be fed with organically produced animal feed. In ruminant ratios, raw feed, such as silage and fodder, should constitute at least $60 \%$ of ration dry substance;

(4) Antibiotics, coccidiostats, medical products or other substances used to promote growth or production can not be used in animal feed;

(5) There are some conditions related to animal raising applications, sheltering of animals and their care. Operations, such as castration, dehorning and ear-piercing, can be allowed by organizations authorized for the safety, health, comfort and hygiene of animals in organic animal breeding;

(6) Feed and water must be easily available for animals. Insulation, heating and ventilating of barns should be arranged in such a way as to keep the air flow, dust level, heat, relative humidity and gas intensity within the limits not to be harmful for animals. Natural ventilation and light entrance to barns should be ensured;

(7) Barns should be large enough for animals to make all their natural movements. In organic dairy cattle breeding, $6 \mathrm{~m}^{2}$ should be spared for each animal inside the barn and $4.5 \mathrm{~m}^{2}$ should be spared for each animal to wander apart from the grazing land;

(8) Barns, equipments and containers should be cleaned and disinfected in such a way that disease carrying organisms can not develop and spread. The floors of the shelters should be flat and not be slippery. At least half of the total floor area should be firm and flat;

(9) Except for regular vaccine applications, parasitic treatment and animals diseases which must be fought within the context of animal disease fight program implemented in Turkey, the administration of chemically synthesized veterinary medical products or antibiotics to an animal or an animal group more than 
three times in a year is banned, otherwise the products obtained from concerned animals can not be sold as organic products and the animals are taken into transition period once more.

The transition period is six months for organic milk production and 12 months for meat production in organic breeding. Barns must be redesigned so that cows can behave naturally. Moreover, precautions for animal health and animal welfare must be taken. All cows must be fed with lures produced organically. All precautions must be taken for protecting the flock from diseases. Alternative treatment methods, which leave no track on products, must be deployed primarily in the treatment of diseases.

\section{Organic Dairy Cattle Breeding in the World}

In many countries in the world, many radical changes have been observed in animal production in recent years. For instance, important changes have been made in relation to ingredients of animal feed by considering the triangle of animal, human and environment in the European Union. Though some great developments have been witnessed in the field of animal genetics, sources of animal feed are continuously decreasing. Tendency to exclude animal-based protein sources from ratios, ban imposed on the use of feed components including antibiotic growth hormone and health concerns resulting from meat products, have resulted in the emergence of a new perception of animal production. As a result of raising consciousness of humans and tendency to go back to nature, sensitivity to healthy diet has increased and greater importance has been attached to food safety.

In addition to all the problems related to conventional animal production, increasing interest in animal rights, especially in developed countries, led to more importance to be attached to animal welfare. In recent years, in many countries, as a result of the efforts put forth for the prevention of the problems related to conventional animal production and consideration of animal ethics, special importance has been attached to organic animal production [8].

Today, in countries, such as America, Canada, Australia, Denmark, Germany, England, France and Argentina, great progress has been made in organic animal breeding, and transition to organic production has been completed to a great extent. The leading countries in organic animal production are America and Canada, and after the detection of the fact that some hormones can cause the formation of cancer in humans and animals with laboratory studies, the demand for organic milk and meat has increased. In America, the production of organic milk and milk products accounts for $2 \%$ of the total production of milk and milk products. In Canada, on the other hand, there are 70 certified livestock breeders and nearly seven thousand organic milk cows [9], and Canada Organic Animal Raising Association makes important contributions to the development of organic animal production [10].

In terms of the production of organic milk production, America, Germany, Holland, England, Argentina, Austria, Sweden, France and Denmark are the leading countries. The target of Sweden is to produce $25 \%$ of the total milk production as organic milk up to 2021 [11].

In a study conducted in England, it was found that the main reason for the preference of organic products is their being healthy and tasty. On the other hand, it is emphasized that there is not much scientific evidence showing that organic products have some additional advantages over conventional products, it is very difficult to quantitatively prove that these products are more tasty, and more importantly, the processing procedures of organic products do not guarantee that these products will not be contaminated [12].

According to 2009 data [13], United Kingdom among European Union countries comes first with 145,101 organic cows. It is followed by Austria, France and Denmark. In Denmark, organic milk is the 
symbol of organic development. State subsidy is quite high. In France, milk production sector is the fastest growing sector in organic product market [13].

\section{Organic Dairy Cattle Breeding in Turkey}

In Turkey, organic agricultural activities started with vegetative production in 1986. Organic dairy cattle breeding is a newly developing sector in Turkey. The first organic milk production activities were first initiated with the establishment of Organic Dairy Cattle Breeding Organization by Dogan Organic Products Industry and Trade Inc., in Kelkit in 2002. After taking its certificate in 2005, the organization started production and launched its organic milk into the market [14].

While in 2005, there were 725 cattle organically raised and 1,350 tons of organic milk production; in 2011, the number of cattle increased to 3,338 and total production of organic milk increased to 14,078 tons; and in 2014, the number of cattle became 3,760 and total production of organic milk increased to 51,906 tons in Turkey (Table 1) [15].

From Table 1, it is seen that the number of dairy cattle, manufacturers and total milk production increased in 2014 when compared to 2011. Though there is no specific region coming to the fore in organic milk production in Turkey, in cities, such as Gumushane, Van and Erzincan, organic dairy cattle breeding activities are more intense. It is reported that some regions in Turkey, such as Central Anatolia, Southeast Anatolia and particularly East Anatolia, are not much suitable for organic cattle breeding because of their contaminated lands, local cattle species and cattle raising organizations mostly capitalizing on conventional cattle breeding methods [16]. Through piloting applications, organic dairy cattle breeding should be promoted in these regions and manufacturers should be encouraged with incentives, such as subsidies and marketing supports.

In Turkey, particularly the East Anatolian region and Central Anatolian region and Southeast Anatolian region hold great potentials for organic animal farming with their unpolluted soils, local cattle gene resources and animal breeding organizations.

Despite the positive outcomes of organic plant production, the targeted and expected outcomes have not been attained in organic animal production. While there are many reasons behind this, the most important

Table 1 The number of organic dairy cattle and the amount of milk produced in Turkey [15].

\begin{tabular}{|c|c|c|c|c|c|c|c|}
\hline \multicolumn{4}{|c|}{2011} & \multicolumn{4}{|c|}{2014} \\
\hline Province & $\begin{array}{l}\text { The number } \\
\text { of animals }\end{array}$ & $\begin{array}{l}\text { Number of } \\
\text { manufacturers }\end{array}$ & $\begin{array}{l}\text { Total milk } \\
\text { production (tons) }\end{array}$ & Province & $\begin{array}{l}\text { The number of } \\
\text { animals }\end{array}$ & $\begin{array}{l}\text { Number of } \\
\text { manufacturers }\end{array}$ & $\begin{array}{l}\text { Total milk } \\
\text { production (tons) }\end{array}$ \\
\hline Ardahan & 1 & 825 & 1,954 & Ardahan & 1 & 12,857 & 18,514 \\
\hline Aydın & 1 & 214 & 1,380 & Aydın & 1 & 214 & 1,708 \\
\hline Bursa & 1 & 12 & 60 & - & - & - & - \\
\hline Canakkale & 1 & 227 & 1,869 & Canakkale & 1 & 451 & 1,959 \\
\hline Erzincan & 5 & 187 & 1,025 & Erzincan & 3 & 268 & 1,088 \\
\hline Gumushane & 10 & 1,334 & 7,323 & Gumushane & 7 & 531 & 1,148 \\
\hline Igdır & 1 & 418 & - & Igdır & 1 & 157 & 222 \\
\hline \multirow[t]{8}{*}{ Manisa } & 4 & 121 & 468 & Manisa & 1 & 1,102 & 4,335 \\
\hline & & & & İzmir & 1 & 30 & 65 \\
\hline & & & & Kars & 1 & 14,078 & 18,424 \\
\hline & & & & Kastamonu & 1 & 84 & 512 \\
\hline & & & & Erzurum & 1 & 1,248 & 2,538 \\
\hline & & & & Samsun & 1 & 249 & 902 \\
\hline & & & & Van & 5 & 438 & 491 \\
\hline & & & & Bitlis & 1 & 56 & - \\
\hline Total & 24 & 3,338 & 14,078 & Total & 26 & 3,760 & 51,906 \\
\hline
\end{tabular}


problem is high prices of organic feeds, due to inadequate production of organic animal feeds. Though there has been some increase in animal, meat and milk production in the recent years, this increase seems to be inadequate.

\section{Results and Suggestions}

In Turkey, areas not polluted from intense agricultural and industrial activities, particularly in the East Anatolian region, have great potentials for organic animal husbandry. However, factors, such as problems experienced in the export of animal products due to animal diseases in the country, lack of demand resulting from low purchasing power of the domestic consumers and low level of consumer consciousness, have negative effects on the development of organic animal production. Not only for export, but also for the protection of environment and ecology and consumption of healthier foods by Turkey people, research and production works on organic animal production should be encouraged and promoted. When Turkey's potential for ecological animal production capacity is utilized well, there is a chance to turn disadvantages into advantages in animal production. In Turkey, organic dairy cattle production tends to improve, but it is not at the desired level now.

Organic dairy cattle breeding is rapidly growing in developed and developing countries. In addition to this, considering the general structural features of dairy cattle breeding, the future of dairy cattle breeding in Turkey seems to be promising.

Following suggestions can be made for Turkey to take its place in organic dairy production market in the world. Technical information should be provided for manufacturers about organic dairy cattle breeding. All state and private organizations involved in organic dairy cattle breeding should work in cooperation and share their information. Determination of the efficiency of organizations that are in the business of organic dairy cattle breeding and conducting researches on solving different problems of these organizations are of great importance. Some research should focus on the factors affecting productivity in organic dairy cattle breeding organizations. Legal regulations related to grazing lands which are the main feed sources of organic dairy animals should be immediately passed. The effect of organic conditions on dairy cattle breeding should be investigated in terms of climatic and environmental conditions. The number of organizations engaged in organic animal production is increasing; yet, the amount of research on this issue is quite low. Domestic and international markets should be created for organic milk and dairy products. Regular controls should be made to enhance consumers' trust in organic products. Manufacturers engaged in organic dairy cattle breeding should be organized under the roof of an association, which will help them to keep records, to process products, to market and to obtain technical support. The high cost of audition and certification should be reduced.

If the above-mentioned suggestions are taken into consideration, then the market share of Turkey having unique natural resources for organic dairy cattle breeding in the world market of organic dairy products particularly in that of European Union will be increased.

\section{References}

[1] Sayan, Y., and Polat, M. 2006. General Principles of Organic Livestock Production. Istanbul: International Competitiveness Research Institute Association.

[2] Demirhan, S. A., and Unal, N. 2013. "Organic and Conventional Dairy Cattle Breeding Done Business in Milk Yield and Milk in the Comparison of Quality Characteristics." Presented at the Second Turkey Organic Livestock Congress, October 24-26, 2013, Bursa.

[3] Cavdar, Y. 2007. "Overview of Organic Agriculture and Organic Aquaculture." Accessed February 10, 2015. http://www.yunus.sumae.gov.tr.

[4] T.C. Resmi Gazete. 2010. "Regulations for the Implementation of the Principles of Organic Agriculture." Official Gazette. Accessed April 16, 2015. http://www.resmigazete.gov.tr/.

[5] Ak, İ., and Karaman, S. 2008. Livestock in Organic Agriculture. Organic Farming and the Environment. 
Bursa: Ozsan Publishing.

[6] Bayram, B., Yolcu, H., and Aksakal, V. 2007. "Organic Agriculture and Problems in Turkey." Ataturk Univ. Agriculture Fak. Journal 38 (2): 203-6.

[7] T.C. Resmi Gazete. 2004. "Organic Farming Law." Official Gazette. Accessed January, 06, 2015. http://www.resmigazete.gov.tr/.

[8] Aksoy, U., Tuzel, Y., Altındisli, A., Can, H. Z., Onogur, E., Anac, D., Okur, B., Cicekli, M., Sayan, Y., Kırkpınar, F., Kenanoglu Bektas, Z., Celik, S., Arın, L., Er, C., Ozkan, C., and Ozenc, D. B. 2005. "Organic Farming Practices.” Accessed April 20, 2011. http://www.zmo org.tr/etkinlikler/6tk05/016uygunaksoy.

[9] Macey, A. 2006. "Certified Organic Production in Canada." Accessed September 10, 2007. http://www4.agr.gc.ca/resources/prod/doc/misb/hort/orgbio/pdf/certifiedorganicproduction.

[10] Saner, G., and Engindeniz, S. 2007. "Transition to Organic Production Facilities and Animal Husbandry, Turkey." Accessed May, 12, 2010. http://www.ekolojiktarim.org/admin/uploaded/20050320 _1540_28.doc.

[11] Ekoorganik. 2015. "Quality Factors in Milk." Pınar Organic Milk. Accessed February 15, 2015. http://www.ekoorganik.com/katagori/gida/sut_urunlari/pi nar.

[12] Kouba, M. 2003. "Quality of Organic Animal Products." Livest. Prod. Sci. 80 (1-2): 33-40.

[13] Say, D., and Guzeler, N. 2010. "Organic Milk and Dairy Products." Presented at the First Turkey Organic Livestock Congress, July 1-4, 2010, Gumushane.

[14] Doğan Holding. 2016. "Organic Milk Dogan Organic Products.” Accessed January 04, 2016. http://www.doganholding.com.tr/yatirimlar/dogan-organi k-urunler.

[15] Food, Agriculture and Livestock Ministry. 2014. “Organic Animal Data.” Accessed June 16, 2014. http://www.organik.tarim.gov.tr.

[16] Aksakal, V., Akbulut, O., Bayram, B., and Esebbuga, N. 2010. "Organic Meatand Dairy Cattle." Presented at the First Turkey Organic Livestock Congress, July 1-4, 2010, Gumushane. 